\title{
POCHAYIV LAVRA IN THE PERIOD OF ACQUISITION OF AUTOCEPHALY BY UKRAINIAN ORTHODOX CHURCH: POSITION, DEMONSTRATION OF REACTION, PROSPECTS
}

\author{
Rychko Viktoriya, PhD student, Ukraine, Rivne, Rivne State University of Humanities
}

DOI: https://doi.org/10.31435/rsglobal_ijitss/31052020/7056

\section{ARTICLE INFO \\ Received 29 March 2020 \\ Accepted 22 May 2020 \\ Published 31 May 2020}

\section{KEYWORDS}

Ukrainian Orthodox Church, Russian Orthodox Church, Ukrainian Orthodox, autocephality, Holy Dormition Pochayiv Lavra.

\begin{abstract}
The article studies the reaction of famous monastic vow in Ukraine - The Holy Dormition Pochayiv Lavra on the acquisition of autocephality by Ukrainian Orthodox. Through the lens of facts proving its activity, it is explained that in the activation process of getting tomos of autocephality by the Orthodox Church of Ukraine, Pochayiv Lavra demonstrated the opposition to initiatives, directed at the formation of Ukrainian Orthodox national character. The document, which officially declared it, was "Address of Metropolitan Volodymyr, Father Superior of the Holy Dormition Lavra, regarding risk and "tomos"". The destructive activity of Pochayiv Lavra concerning the problem of overcoming the Orthodox conflict in Ukraine was demonstrated in mobilization of its piligrims to the participation in the acts that were pseudo-protest movements in nature, which were aimed at the destabilization of Ukrainian society and activation of intrapublic protests. In the end it could have been the reason not only for the interruption or even cancellation of the religious and church project of acquiring the status of Local Church by Ukrainian Orthodox Church, but in wider context - the significant slowdown of the consolidation of Ukrainian society and rollout of its national identity accumulation process.
\end{abstract}

Citation: Rychko Viktoriya. (2020) Pochayiv Lavra in the Period of Acquisition of Autocephaly by Ukrainian Orthodox Church: Position, Demonstration of Reaction, Prospects. International Journal of Innovative Technologies in Social Science. 4(25). doi: 10.31435/rsglobal_ijitss/31052020/7056

Copyright: (C) 2020 Rychko Viktoriya. This is an open-access article distributed under the terms of the Creative Commons Attribution License (CC BY). The use, distribution or reproduction in other forums is permitted, provided the original author(s) or licensor are credited and that the original publication in this journal is cited, in accordance with accepted academic practice. No use, distribution or reproduction is permitted which does not comply with these terms.

Вступ. 11 жовтня 2018 р. Святий і Священний Синод Константинопольского патріархату ухвалив історичне рішення про повернення Київської митрополії до складу Вселенської патріархії. Вже 6 січня 2019 р. у резиденції Константинопольського патріарха у Стамбулі відбулося урочисте вручення томосу про автокефалію главі Православної Церкви України митрополиту Епіфанію (Думенко). Реакція на цю без перебільшення епохальну для України і українського православ’я подію з боку як РПЦ, так і УПЦ (МП) як ії складової, була цілком прогнозованою, оскільки їхня позиція у цьому питанні була перманентно негативною й визначалася політикою блокування самої ідеї автокефалії. На думку В. Сленського, це пояснюється тим, що за кулісами процесу набуття УПЦ автокефалії знаходилося «дуже мало богослов'я і дуже багато політики, навіть геополітики», а ті, хто боровся за збереження статускво в українському православ'ї і проти набуття ним томосу, той хотів «залишити Україну в орбіті Росії» [4]. Відтак, питання набуття автокефалії ПЦУ виявилося рівнозначним проблемі національної безпеки України, зокрема, іiі визволення з-під впливу реактивної духовної інтервенції Москви. Надзвичайно гостра реакція РПЦ і ії структурної частини - Почаївської Свято-Успенської лаври УПЦ (МП) на отримання томосу Православною Церквою в Україні актуалізує окреслену тему дослідження та визначає його мету. 
Результати дослідження. Непоступливість і категоричність позиції РПЦ у питанні набуття українським православ'ям автокефалії прослідковується на прикладі оприлюдненої на початку вересня 2018 р. офіційної заяви ії керівництва про те, що воно розірве євхаристійне спілкування з Константинопольським Патріархатом у випадку, якщо Православна Церква в Україні отримає автокефалію [15]. У іншій, не менш гучній заяві речника РПЦ, голови Відділу зовнішніх церковних зв'язків Московського Патріархату, митрополита Іларіона (Алфєєва) містилося твердження, що надання Українській Церкві автокефалії «може призвести до кровопролиття». Особливо його непокоїла доля УПЦ (МП), яка з набуттям статусу Церкви країни-агресора може втратити свої «законні права», зокрема контроль над Києво-Печерською та Почаївською лаврами. Саме це, на його думку, спровокує кровопролиття, оскільки «православні віряни будуть захищати ці святі місця» [16].

Відповідний настрій спостерігався в цей період й у Почаївській лаврі. Його зафіксувала журналістка Г. Терещук й висвітлила у публікації ««Форпост «русского мира». У Почаївській лаврі готуються протистояти автокефальній українській церкві?» [19]. На їі думку, виявами напруженого очікування керівництва цього чернечого осередку в контексті майбутнього набуття Українською Церквою помісності стало збільшення чисельності охорони монастиря, ретельний огляд паломників при вході на його територію, а також уникання керівництвом обителі контактів із медіа. Особливо помітною стала присутність великої кількості охоронців на лаврських богослужіннях. Саме цим, на думку опитаних журналісткою паломників, нагнітається відчуття, «що може бути якась сутичка, якщо Україна отримає томос». Мешканець Почаєва А. Голуб висловив припущення, що суттєве збільшення охорони місцевої лаври насправді пов'язане з тим, що ії очільники «бояться народу». Саме тому в цей непевний період вони «будуть обережніші у висловлюваннях». Однак, на його переконання, «Політика в лаврі не зміниться», оскільки це «форпост «русского мира» [19].

Показовим у контексті негативної реакції керівництва Почаївської чернечої обителі щодо набуття українським православ'ям помісності стало «Звернення Намісника Свято-Успенської Лаври Митрополита Володимира 3 приводу загрози і «томосу»», оприлюднене в жовтні 2018 р. [7]. У ньому очільник Почаївської лаври назвав томос «оманою», бо, за його словами, «Наша Українська Православна Церква має канонічний статус, визначений Томосом від 27 жовтня 1990 р. від Матері Церкви». Зауважимо, що під «Матір’ю Церквою» тут розуміється РПЦ. Однак, як стверджує впливовий грецький ієрарх, член Синоду Вселенської патріархії, митрополит Елпідофор, ця думка $є$ хибною, викривленою, оскільки «Московська Церква є дочкою Київської Церкви, яка Українська Церква - є дочкою Вселенського Патріархату» [23].

Далі у «Зверненні» намісника Почаївської обителі йдеться про те, що «ми задоволені тим статусом, який має наша Церква» 3 відсиланням на відповідні документи, зокрема грамоту патріарха Алексія II, яка декларує незалежність і самостійність управління УПЦ. Водночас у своєму звертанні до громадськості цей ієрарх вказав, що «Новий стиль 3 його наслідками нам православним неприємлемий», тобто, по суті, категорично відкинув ідею помісності Православної Церкви в Україні. Й хоча ці тези виписані ним доволі безапеляційно, однак насправді в цьому документі насторожує інше, а саме практично неприховані заклики до вірян у випадку «загрози» «захистити свою святиню» [20]. Для цього, як йдеться у «Зверненні», потрібна буде їхня «фізична присутність». Звернемо увагу на те, що єдиним виділеним місцем у його тексті є наступний фрагмент: «Додатково ми постараємося Вас поінформувати коли приїхати...» (так виділено в тексті. - В. Р.) [7; 19]. Дієвого захисту вірян просила у своєму зверненні також братія Почаївської лаври, яка під процесом конституювання єдиної української помісної Православної Церкви вбачала не що інше, як «знищення канонічної православної церкви і Апостольської віри в Україні» [1]. Відтак, у контексті провідних тенденцій сучасної ситуації в українському православ'ї вказане «Звернення Намісника Свято-Успенської Лаври Митрополита Володимира 3 приводу загрози і «томосу»» $є$ не тільки яскравим виявом позиції протистояння ініціативам, спрямованим на формування національного характеру українського православ'я, але й чинником дестабілізації вітчизняного соціуму, а також одним із засобів створення внутрішньої напруги в ньому.

За спостереженням журналіста М. Лісковича, котрий відвідав Почаївську лавру в жовтні 2018 р. й безпосередньо поспілкувався як із паломниками, так і чернечою братією, а також студентом Почаївської духовної семінарії, свідомість більшості 3 них уражена 
ідеологічним вірусом «русского мира», в основі якого знаходиться ідея «Москва - третій Рим». Це підтверджується тим, що «Їм би хотілося, щоб усі православні були підпорядковані Москві, як католики - іспанці, французи, поляки, бразильці - Риму першому» [11]. Продовжуючи цю думку, зауважимо, що при цьому у католиків - тих же іспанців, французів, поляків, бразильців тощо - не відбирають право бути незалежними націями. Чого не скажеш про постулати «русского мира», згідно яких усі православні - не лише один народ, але й одна держава.

На стадії активізації процесу набуття українським православ'ям автокефалії проросійські церковні структури в Україні здійснили численні спроби не лише його дискредитації, але й перешкоджання, а також згортання. Так, під час урочистостей 3 нагоди 1030-ліття Хрещення Русі їхні потуги були спрямовані на те, щоб показати масовість прихильників УПЦ (МП) шляхом проведення під час святкової хресної ходи провокації під виглядом сутичок «фашистів i націоналістів». Крім того, з ініціативи Предстоятеля УПЦ (МП) митрополита Онуфрія 28 липня 2018 р. у Києві на території Києво-Печерської лаври було запланована зустріч очільників цієї Церкви з представниками іноземних посольств в Україні, а саме Російської Федерації, Білорусі, Молдови, Грузії, Греції, Кіпру, Сербії, Македонії, Болгарії і Румунії. Водночас на неї було запрошено ієрархів Сербської, Македонської, Болгарської, Грузинської, Білоруської, а також Американської Православних Церков. У рамках цієї зустрічі було заплановане обговорення подій навколо «неканонічного процесу» надання автокефалії УПЦ. Як твердив із цього приводу Д. Тимчук, «Присутніх, згідно з тезами Москви, а також сформованої під час Хресного ходу «потрібної картинки», будуть переконувати в небезпеці такого розвитку ситуації» («загроза розколу світового православ'я», «криваве протистояння в Україні на релігійному грунті» тощо). Акцентуємо, що головна теза організаторів цього заходу зводилася до заклику об'єднання, щоб «спільними зусиллями зберегти мир на українській землі» [12]. На нашу думку, за умов окупації Росією Сходу України ця демонстрація намірів УПЦ (МП) є доволі цинічною.

Водночас дієву участь в акціях, спрямованих на гальмування процесу конституювання української помісної Православної Церкви, взяли «православні тітушки» з Почаївської лаври. Як стало відомо, восени 2018 р. мобілізованих цим промосковським чернечим осередком вірян відправляли мікроавтобусами до Києва на організовані акції протесту [9]. За інформацією СБУ, завдання відряджених до Києва полягало в тому, щоб блокувати резиденції, де проживали константинопольські екзархи, котрі були задіяні в процедурі надання Україні томосу про автокефалію. Водночас їхня безпосередня присутність була передбачена в низці інсценувань i провокацій, пов'язаних із захопленням культових споруд під виглядом представників праворадикальних організацій [25]. Отже, дії православних пікетувальників із Почаївської лаври УПЦ (МП) мали характер псевдопротестних виступів, спрямованих на збурення української громадськості, активізацію внутрішньосуспільних протистоянь, що в кінцевому підсумку могли б стати підставою не лише для призупинення, але й скасування процесу набуття Українською Православною Церквою автокефалії.

Завершальний етап набуття ПЦУ автокефального статусу зумовив черговий інформаційний вал з боку як РПЦ, так і проросійських церковних структур в Україні. Зокрема, події 11 жовтня 2018 р., а саме ухвалення рішення Синоду Вселенського патріархату про надання томосу про автокефалію Православній Церкві в Україні викликало гостру реакцію офіційного керівництва РПЦ, яке вже 15 жовтня розірвало євхаристійне спілкування із Вселенським патріархатом, оскільки, за словами голови відділу зовнішніх церковних зв'язків Московського патріархату митрополита Іларіона, ухвали Константинополя щодо підтримки ідеї помісної Православної Церкви в Україні є «незаконні та канонічно нікчемні» [21]. Зрештою, 20 жовтня 2018 р. РПЦ оголосила Константинопольского патріарха Варфоломія «розкольником» [17]. В унісон цій заяві прокремлівських духовних очільників було підготовлене офіційне звернення голови інформаційно-просвітницького відділу УПЦ (МП) архієпископа Климента (Вечері), де йшлося про те, що «Підписання томосу про автокефалію для Православної церкви України відбулося із порушенням фундаментальних канонічних церковних правил». Категоричним стало твердження архієпископа Климента й щодо Константинопольського патріарха Варфоломія, котрий, на його думку, «співслужив розкольникам», а «Згідно апостольських і святоотцівських правил, той, хто співслужить розкольникам, сам $є$ таким, що ухилився в розкол» [3]. 
Після набуття українським православ'ям помісності до подібних гучних заяв керівників РПЦ і УПЦ (МП) додалися тези на кшталт: 1) конституювання ПЦУ є одним із кроків утвердження державної Церкви; 2) ПЦУ не «канонічна», а тому «розколює» українське православ’я і веде його до унії з Римом. Так, у заяві Священного Синоду УПЦ (МП) від 3 квітня 2019 р. томос про автокефалію ПЦУ названий антиканонічним, й таким, що завдав «великої шкоди» українському православ’ю, а також став «загрозою для всеправославної єдності». На думку ієрархів УПЦ (МП), Константинопольський Патріархат припустився грубої помилки, яку слід негайно виправити, а саме відкликати наданий ним томос. У цьому документі також містилося звернення до представників державної влади з вимогою скасувати Закон України №2673-VIII від 17.01.2019 року про перейменування Української Православної Церкви, який було названо антиконституційним [5]. Як твердить із цього приводу С. Здіорук, подібні висловлювання промосковських пропагандистів мають на меті нівелювання значимості факту проголошення автокефалії ПЦУ. 3 огляду на це вони $€$ нічим іншим, як інформаційною складовою гібридної війни Росії проти України, що виступає чинником суттєвого гальмування консолідації українського суспільства та згортання процесів кристалізації його національної ідентичності $[8$, с. 3].

Ще одним прикладом нагнітання напруги в українському суспільстві проросійською УПЦ (МП) після отримання ПЦУ томосу про автокефалію став інспірований нею ажіотаж навколо переходу низки іiі релігійних громад під юрисдикцію ПЦУ. Так, за даними РІСУ, станом на середину лютого 2019 р. у лоно ПЦУ перейшли 370 парафій УПЦ (МП). Зауважимо, що вона визнала легітимним перехід лише невеликої їх частини, а переважну більшість близько 300 переходів - назвала «фейковими заявами», тобто категорично не погодилася 3 їхньою зміною юрисдикційної приналежності [22]. Зрештою, декларуючи «факти масових порушень прав людини в Україні та реальну загрозу ескалації релігійних конфліктів», УПЦ (МП) звернулася з відповідним офіційним зверненням до європейської громадськості. У ньому, зокрема, йшлося про те, що «Сьогодні храми нашої Церкви, яка має тисячолітню історію, захоплюють, віруючих б’ють, а державні чиновники примушують священнослужителів УПЦ переходити в підтримувану Президентом України «нову Церкву» [6]. На думку експертів, така позиція очільників УПМ (МП), коли ухвалене конкретною релігійною громадою рішення про зміну юрисдикції інтерпретується нею виключно як факт «масового захоплення храмів», $\epsilon$ абсурдною, оскільки вказує на їі небажання визнавати право релігійних громад не лише робити власний вибір, але й вирішувати свою долю. Так, за словами директора департаменту у справах релігій та національностей Міністерства культури України А. Юраша, «Для них громада якась структурна одиниця, яка довічно, до другого пришестя, має перебувати у феодальному володінні МП» [13]. Як висновує цей урядовець, вказані прагнення УПЦ (МП) знаходяться на поверхні інспірованих нею окремих виявів суспільного хвилювання. В цьому контексті зауважимо, що вітчизняне законодавство уможливлює абсолютно вільну трансформацію юрисдикційної приналежності будь-якої релігійної громади. Водночас, згідно нього, саме релігійна громада володіє усім майном, і лише вона має повне право ним розпоряджатися. Однак УПЦ (МП) категорично виступає проти цих законодавчих ухвал. Саме тому вона називає переходи релігійних громад до іншої юрисдикції «захопленнями храмів», що насправді не відповідає дійсності [13].

Аналогічні інсинуації проросійських ЗМІ відбулися й навколо найбільших чернечих осередків УПЦ (МП) - Києво-Печерської і Почаївської лавр. Так, прикладами брехні та дезінформації назвав патріарх Філарет заяви представників УПЦ (МП) про силовий сценарій їхнього захоплення, а також можливість «громадянської війни» через набуття ПЦУ автокефалії [14]. Як твердить із цього приводу директор департаменту у справах релігій та національностей Міністерства культури України А. Юраш, подібні декларації УПЦ (МП) $\epsilon$ елементом інформаційної протидії створенню помісної Церкви. Водночас вони $\epsilon$ прикладом продуманої маніпуляції УПЦ (МП), котра в будь-який спосіб намагається досягнути того, щоб усе майно парафії було закріплене за Церквою, а не за конкретною релігійною громадою, тобто, по суті, обійти українське законодавче поле [2]. На нашу думку, іiї безперспективність яскраво прослідковується на прикладі повернення низки споруд Свято-Успенської Почаївської лаври до складу Кременецько-Почаївського заповідника, що відбулося в листопаді 2018 р. Тоді уряд України ухвалив рішення про скасування їхньої незаконної перереєстрації 2003 р., за якою вони надавалися в оренду Московському Патріархату терміном на 49 років [10]. 
Щоправда, повернення майна Почаївської лаври Українській державі не означало автоматичного переходу цієї чернечої обителі під юрисдикцію помісної ПЦУ. Після Об'єднавчого Собору Православних Церков, що відбувся 15 грудня 2018 р. у Києві, Почаївська лавра продовжує залишатися складовою частиною УПЦ (МП). За оцінкою фахівців, ії̈ приєднання до ПЦУ цілком можливе, але лише внаслідок «еволюційного процесу», а також реального волевиявлення насельників і керівництва, але ніяк не примусу [2]. На нашу думку, з огляду на характер і спрямованість діяльності Почаївської лаври впродовж останніх 10-ти років, це відбудеться не скоро. Як показали події навколо набуття УПЦ автокефального статусу, цей видатний чернечий осередок, як, зрештою, й переважна більшість інших релігійних громад УПЦ (МП), зайняли безкомпромісну позицію протистояння націєтворчим устремлінням українців. Саме тому реалізація їхніх прагнень мати не лише помісну Православну Церкву, але й єдину релігійну ідентичність, що стала б вагомим чинником консолідації вітчизняного соціуму, відтермінована на невизначений строк. Як твердить із цього приводу Ю. Чорноморець, «Єдина релігійна ідентичність для кількох (багатьох) релігійних груп не може народитися на протистоянні». За ним, iï формування відбудеться лише за умови конструктивного позитивного творення [24]. О. Саган також наголошує на мирності вирішення спірних питань в сучасному українському православ'ї, яку уможливить лише усвідомлення всіма сторонами конфлікту його історичних передумов та особливостей. В першу чергу це стосується духовенства і вірян УПЦ (МП), котрі нині гостро потребують реабілітації історії Православної Церкви в Україні [18, с. 73-74].

Висновки. Впродовж усього періоду незалежності України діяльність РПЦ, а також УПЦ (МП) як іiі складової частини щодо питання помісності українського православ'я визначалася політикою блокування ідеї його автокефалії. Керівництво і насельники Почаївської СвятоУспенської лаври у період активізації процесу отримання ПЦУ томосу про автокефалію продемонстрували позицію протистояння ініціативам, спрямованим на формування національного характеру українського православ'я. Документом, який офіційно декларував ії, стало «Звернення Намісника Свято-Успенської Лаври Митрополита Володимира з приводу загрози і «томосу»»». У ньому очікувана українським народом грамота про автокефалію названа «оманою», а РПЦ «Матір’ю Церквою» Української Православної Церкви. Водночас виявом деструктивної діяльності Почаївської лаври стосовно проблеми подолання православного конфлікту в Україні стала мобілізація iі паломників на участь в акціях, що мали характер псевдопротестних виступів, спрямованих на збурення української громадськості та активізацію внутрішньосуспільних протистоянь. У підсумку це мало стати підставою не лише для призупинення або ж навіть скасування релігійно-церковного проекту набуття Українською Православною Церквою помісності, але в ширшому контексті - суттєвого гальмування консолідації українського суспільства та згортання процесів кристалізації його національної ідентичності.

Однією з передумов вірогідного приєднання Почаївської лаври до помісної ПЦУ стало повернення у листопаді 2018 р. іiі споруд до складу Кременецько-Почаївського заповідника. Однак після Об'єднавчого Собору Православних Церков, що відбувся 15 грудня 2018 р. у Києві, Почаївська лавра продовжує залишатися складовою частиною УПЦ (МП), оскільки безпосередньою підставою іiі входження до складу помісної ПЦУ має бути реальне волевиявлення iї керівництва і насельників, а не примус. Для цього потрібен час, а головне проведення відповідної практичної роботи 3 формування їхнього внутрішнього запиту i переконаності в необхідності помісності ПЦУ. Тоді Почаївська лавра могла б стати не лише одним із національних символів прогресивного поступу України i духовних атрибутів української ідентичності, а що важливіше - їхнім каталізатором.

\section{ЛІТЕРАТУРА}

1. Брик A. Що принесе томос у Почаївську лавру? URL: https://zik.ua/news/2018/12/10/shcho_prynese_tomos_u_pochaivsku_lavru_1466191

2. В очікуванні томосу: у Кабміні розповіли про подальшу долю Почаївської лаври. URL: https://www.pravda.com.ua/news/2018/11/28/7199627/

3. В УПЦ (МП) назвали томос для української церкви «спокусою». URL: https://www.bbc.com/ukrainian/news-46769584

4. Єленський В. У питанні автокефалії дуже мало богослов'я і дуже багато політики. URL: https://www.radiosvoboda.org/a/речники-київського-і-московського-патріархатів-про-томос-іреакцію-рпц/29336506.html 
5. Заява Священного Синоду УПЦ щодо ситуації в українському і світовому Православ'ї від 3 квітня 2019 p. URL: https://news.church.ua/2019/04/03/zayava-svyashhennogo-sinodu-upc-shhodo-situaciji-vukrajinskomu-i-svitovomu-pravoslavji/

6. Звернення голови Представництва УПЦ при європейських міжнародних організаціях до офіційних осіб ООН, ОБСС, СС та інших країн у зв'язку з фактами масових порушень прав людини в Україні та реальною загрозою ескалації релігійних конфліктів (+ відео). URL: https://news.church.ua/2019/02/18/zvernennya-golovi-predstavnictva-upc-pri-jevropejskix-mizhnarodnixorganizaciyax-do-oficijnix-osib-oon-obsje-jes-ta-inshix-krajin-u-zvyazku-z-faktami-masovix-porushenprav-lyudini-v-ukrajini-ta-re/

7. Звернення Намісника Свято-Успенської Лаври Митрополита Володимира 3 приводу загрози i «томосу». URL: http://www.pochaev.org.ua/?pid=2123

8. Здіорук C. I. Московський патріархат як механізм деструкції національної єдності в Україні. URL: https://niss.gov.ua/sites/default/files/2019.pdf

9. Ілюк Т. У Почаївській лаврі на Тернопільщині масштабна мобілізація (фото, відео). URL: https://www.0352.ua/news/2171834/u-pocaivskij-lavri-na-ternopilsini-masstabna-mobilizacia-foto-video

10. Кабмін повернув Почаївську лавру Кременецько-Почаївському заповіднику. URL: https://www.pravda.com.ua/news/2018/11/28/7199595/

11. Ліскович М. Чим живе Почаївська Лавра - форпост «руського міра» на Заході України// Укрінформ. Мультимедійна платформа іномовлення України. URL: https://www.ukrinform.ua/rubricsociety/2562165-cim-zive-pocaivska-lavra-forpost-ruskogo-mira-na-zahodi-ukraini.html

12. Московський патріархат лякатиме послів «небезпечною автокефалією» - Тимчук // Укрінформ. Мультимедійна платформа іномовлення України. URL: https:/www.ukrinform.ua/rubricsociety/2503771-moskovskij-patriarhat-lakatime-posliv-nebezpecnou-avtokefalieu-timcuk.html

13. Назвали кількість громад Московського патріархату, які перейшли до Київського за час війни. URL: https://p-p.com.ua/news/nazvaly-kilkist-gromad-moskovskogo-patriarkhatu-pereishly-do-kyivskogo-zachas-viiny/

14. Ніхто не піде «захоплювати Лавру» - патріарх Філарет прокоментував публікації у 3MI. URL: https://www.radiosvoboda.org/a/29407577.html

15. Російська церква погрожує розірвати зв'язки з Константинополем в разі надання автокефалії УПЦ. URL: https://www.radiosvoboda.org/a/news-rpc-rozirve-konstantynopol-avtokefalia/29479057.html

16. РПЦ: надання Україні автокефалії може призвести до кровопролиття. URL: https://www.radiosvoboda.org/a/news-rpc-ukraina-avtokefalia/29491723.html

17. РПЦ оголосила Вселенського патріарха розкольником. URL: https://www.ukrinform.ua/rubricworld/2562919-rpc-ogolosila-vselenskogo-patriarha-rozkolnikom.html

18. Саган О. Н. Православна Церква України: конституювання та перспективи розвитку. - К.: ТОВ «Софія-А» ЛТД, 2019. - 103 с.

19. Терещук Г. «Форпост «русского мира». У Почаївській лаврі готуються протистояти автокефальній українській церкві? URL: https://www.radiosvoboda.org/a/pochayivska-lavra-avtokefaliia/29489759.html

20. У наданні Україні томосу Почаївська лавра вбачає загрозу і гуртує прихожан (відео). URL: https://www.youtube.com/watch?v=pjy9ck7oXQE

21. Хоменко С., Голубєва А. РПЦ розірвала стосунки з Константинополем: що це означає. URL: https://www.bbc.com/ukrainian/news-45865460

22. Червоненко В. Скільки громад перейшли від УПЦ МП до ПЦУ і як це рахують. URL: https://www.bbc.com/ukrainian/features-47358722

23. Член Синоду Вселенської патріархії: Московська церква є не матір'ю, а дочкою Української. URL: https://www.ukrinform.ua/rubric-society/2496544-clen-sinodu-vselenskoi-patriarhii-moskovska-cerkva-ene-matiru-a-dockou-ukrainskoi.html

24. Чорноморець Ю. Сучасні проблеми 3 релігійною ідентичністю: трагедія православ'я. URL: https://www.religion.in.ua/main/analitica/10102-suchasni-problemi-z-religijnoyu-identichnistyu-tragediyapravoslavya.html

25. Шевчук Г. 3 Почаївської лаври, що на Тернопільщині, відрядили «православних тітушок». URL: https://www.0352.ua/news/2176232/z-pocaivskoi-lavri-so-na-ternopilsini-do-kieva-vidradili-pravoslavnihtitusok

26. Шевчук Г. Почаївська лавра, що на Тернопільщині, бачить загрозу в наданні Україні томосу i закликає прихожан готуватися (відео). URL: https://www.0352.ua/news/2180690/pocaivska-lavra-so-naternopilsini-bacit-zagrozu-v-nadanni-ukraini-tomosu-i-zaklikae-prihozan-gotuvatisa-video 